\title{
Prostate Cancer Knowledge of a Group of Men
}

\section{Bruna Chaves Santa Cruz de Almeida ${ }^{1}$, Marília Alves ${ }^{2}$, Arleusson Ricarte de Oliveira ${ }^{3}$, Ana Elisa Pereira Chaves ${ }^{4}$, Yanna Gomes de Sousa ${ }^{5}$, Marília Souto de Araújo ${ }^{6}$, Soraya Maria de Medeiros ${ }^{7}$}

\section{Abstract}

Objective: This study investigates the prostate cancer knowledge of a group of men.

Method: It is an exploratory and descriptive study with a quantitative and qualitative approach. The sample was 20 men from the Family Health Unit in the city of Campina Grande/PB. Data collection occurred in September 2012 and had a questionnaire as an instrument.

Results: It was found that men of this study have low socioeconomic conditions. Regarding the knowledge of the prostate cancer symptoms, most of them (28\%) reported difficulty when urinating, and $23 \%$ could not inform about the symptoms. Most of them (70\%) reported to know how to prevent the disease; $65 \%$ reported never having done it prevention. Concerning the information on the disease, $70 \%$ of respondents said to receive information about the disease. In the qualitative analysis, it was found that most men do not know the meaning of prostate cancer, saying they cannot say anything about the disease; others reported knowing the disease through the symptoms and prevention with the exams.

Conclusions: There is an urgent need to consolidate the Human Health National Policy by managers, health professionals, and people throughout the national territory seeking to effect the promotion of men's health to ensure the knowledge about the disease and the adoption of measures to prevent it.
1 Nurse. Graduated from the Medical Science School. Campina Grande (PB), Brazil.

2 Nurse. Ph.D. in Nursing. Professor at the Department of Nursing, Federal University of Minas Gerais MG, Brazil.

3 Nurse. Ph.D. student of the Graduate Program in Nursing, Federal University of Minas Gerais MG, Brazil.

4 Nurse. Ph.D. student of the Graduate Program in Nursing, Federal University of Rio Grande do Norte/UFRN. Natal (RN), Brazil.

5 Nurse. Master student of the Graduate Program in Nursing, Federal University of Rio Grande do Norte/UFRN. Natal (RN), Brazil.

6 Student of Nursing by the Federal University of Rio Grande do Norte/ UFRN. Natal (RN), Brazil.

7 Nurse. Ph.D. in Nursing. Professor at the Department of Nursing, Federal University of Rio Grande do Norte/ UFRN. Natal (RN), Brazil.

Contact information:

Yanna Gomes de Sousa.

झ"yanna_gomes@yahoo.com.br

\section{Keywords}

Prostate Cancer; Men's Health; Knowledge; Prevention. 


\section{Introduction}

Prostate Cancer (PC) is a disease that affects the male population for centuries and is recognized as a global public health problem by its magnitude in mortality, with alarmingly increasing levels [1].

In Brazil, prostate cancer is the second most common malignancy among men (only after nonmelanoma skin cancer). In absolute terms, it is the sixth most common cancer type in the world and the most prevalent in men representing about $10 \%$ of all cancers. Its incidence rate is about six times higher in developed countries compared to developing countries. In 2013, there were 13,772 male deaths due to this disease. The estimated number of cases for 2014 was 68,800 new cases [2].

One of the factors for high morbidity and mortality of prostate cancer is the late diagnosis of the disease. It could be related to factors such as the lack of information of the population, which keeps some outdated and negative beliefs about cancer and its prognosis; prejudice against cancer and against the screening test, especially the rectal; the lack of comprehensive routines programmed in health services, especially in primary care for the male population, with regard to development activities with an emphasis on health promotion and disease prevention in this population.

Also, the cultural and social barriers have a strong influence on the appearance of prostate cancer, hindering the adherence of men in ways of prevention, particularly in the digital rectal examination generating bias in the technique used to perform the exam, somehow invading their manhood [3].

The problem of not seeking the primary service by the male population may increase the chance of a greater problem that could have been avoided by performing actions developed in the Family Health Strategy - FHS. Virility loses due to their role of sexual performance, confusing masculinity with sexual performance is one of the obstacles faced by male [4].
The Brazilian Society of Urology (SBU) [5] recommends that men who are over 50 and those being 40 years old with a family history of prostate cancer, have to think of the possibility of "going annually to the urologist for a check-up the prostate," even if they have not urinary symptoms. Regarding early diagnosis of prostate cancer, it is used to recommend the clinical examination (DRE or digital rectal exam) and the blood test for specific prostate antigen, known as PSA, informing the limitations, the benefits and risks of early detection of prostate cancer.

With the low access of men to the health services, the Ministry of Health in 2008 created the National Integral Attention to Men's Health Policy (PNAISH) [6], that allows the recognition of social determinants and vulnerability of the male population to prevent the harm to human health, promoting access to comprehensive care, and showing the main mortality factors.

Nursing has accumulated a body of empirical techniques and knowledge and today develops theories related to each other trying to explain these facts based on the natural universe. These knowledge and skills accumulated over the centuries contribute today in making health care measures that help in prevention, promotion and rehabilitation of injuries. In the area of oncology nursing, nursing care is provided to patients with cancer, including prevention, promotion, treatment, palliative care, and rehabilitation.

It is important the need for nurses know the community and interact with nursing are in cancer prevention. Thus, a more effective relationship of trust can be established to the community to obtain good results. However, nurses do not seem to be prepared for this practice [7].

In this sense, the Family Health Strategy - FHS allows nurses to know the acting territory of the male population. This professional along with a multidisciplinary team performs a health educator role, acting on issues related to the health of the 
population, working on prevention and promotion of diseases.

Thus, the question is: Does the male population have some knowledge in PC? Do these men know the ways of prevention and symptoms of the disease? Therefore, this study aims to investigate the knowledge on prostate cancer in a group of men.

\section{Methods}

This research is an exploratory and descriptive study with a quantitative and qualitative approach. The quantitative aspect of the research are the quantifiable variables universally, and qualitative aspect works with the meanings of actions, motivations, aspirations, beliefs, values, attitudes and human relationships understood from the researcher's perspective [8]

The study was conducted in the Family Health Strategy - FHS of a municipality in northeastern Paraíba, Brazil. The study population consisted of 20 men aged over 40 years old. The inclusion criteria were living in the FHS coverage area; 40 years old or older. Users who were not mentioned within these criteria were excluded from the sample.

A semi-structured interview was used for data collection conducted in the users' surveyed homes. Data collection was conducted in September 2012. The interviews were recorded and then transcribed and used in this study with the consent of the participants.

Quantitative data were processed using Microsoft Office Excel 2007 program. Absolute frequency and relative percentage tables were constructed. As for the qualitative data, they were fully transcribed, built upon the testimonies and their selected categories. For data analysis, the method of analysis of content proposed by Bardin [9] was used, which reveals that the speech is a fruit under construction and therefore having contradictions and imperfections.

The technique consisted of three major steps: 1) a pre-analysis, made of the organization of material that can use different procedures such as floating reading, assumptions and development of indicators that base the interpretation; Step 2) is the exploration of the material where the data is encoded from registration units and; step 3) which consists of the interpretation and processing of the data, formulating categorization with grouping. The results of this study were discussed and analyzed based on the literature.

This work has complied with the provisions of the resolution of the National Health Council which deals with the ethics of research involving human beings, which includes the following aspects: informed consent of target individuals and the protection of vulnerable groups and the legally disabled individuals. It was approved by the Research Ethics Committee of Higher Education and Development Center with the opinion number: 05811612000005175.

\section{Results and Discussion}

Table 1 shows the sociodemographic data of respondents. Ages ranged from 40 to 60 years, 45\% were 40-49 years old, 30\% were 50-59 years old, $25 \%$ were 60 years old or more. Regarding marital status, most of them were married (60\%).

Table 1. Percentage distribution of variables on the socio-demographic profile of the interviewed participants. Campina Grande/PB, September 2012.

\begin{tabular}{|l|c|c|}
\hline Socio-demographic characteristics & $\mathbf{n}(\%)$ & Total $\mathbf{n}(\%)$ \\
\hline Age & & \\
\hline $40-49$ & $9(45)$ & 20 \\
\hline $50-59$ & $6(30)$ & $(100)$ \\
\hline 60 or more & $5(25)$ & \\
\hline Marital Status & & \\
\hline Single & $2(10)$ & \\
\hline Married & $12(60)$ & \\
\hline Stable Union & $2(10)$ & 20 \\
\hline Divorced & $1(5)$ & $(100)$ \\
Widow & $3(15)$ & \\
\hline
\end{tabular}




\begin{tabular}{|c|c|c|}
\hline Socio-demographic characteristics & n (\%) & Total n (\%) \\
\hline \multicolumn{3}{|l|}{ Education } \\
\hline Incomplete Elementary & $6(30)$ & \multirow{4}{*}{$\begin{array}{c}20 \\
(100)\end{array}$} \\
\hline Complete High school & $4(20)$ & \\
\hline Incomplete High school & $4(20)$ & \\
\hline Illiterate & $6(30)$ & \\
\hline \multicolumn{3}{|l|}{ Family Income (In Minimum Wages) } \\
\hline$<1$ & $9(45)$ & \multirow{4}{*}{$\begin{array}{c}20 \\
(100)\end{array}$} \\
\hline 1 and 2 & $6(30)$ & \\
\hline 3 or 4 & $4(20)$ & \\
\hline 5 or more & $1(5)$ & \\
\hline \multicolumn{3}{|l|}{ Occupation } \\
\hline Seller/salesperson & $2(10)$ & \multirow{6}{*}{$\begin{array}{c}20 \\
(100)\end{array}$} \\
\hline Vigilant/porter & $3(15)$ & \\
\hline Mason & $2(10)$ & \\
\hline Retired & $2(10)$ & \\
\hline Unemployed & $5(25)$ & \\
\hline $\begin{array}{l}\text { General services assistant/pensioner/ } \\
\text { electrician }\end{array}$ & $6(30)$ & \\
\hline
\end{tabular}

Regarding the socio-demographic data research [5] conducted by the Brazilian Society of Urology corroborates the results found in this study. The survey was conducted with 1,061 men, 4070 years old, from ten capital cities in 2009, and they found that the higher the level of education of men and the higher the social class, the greater the care with health. About $79 \%$ of men with college degrees have visited the urologist while 46\% of those with primary education have gone to an expert. Men of Southeast capital are the ones that go to the urologist (62\%) and the men of the North go less (36\%).

Table 2 describes the answers of respondents on their knowledge of the symptoms of PC. It is observed that in the symptoms reported, most of them (27.9\%) reported difficulty urinating; $16.3 \%$ pain when urinating; $9.3 \%$ is urinating aplenty. It is also noted that $23.3 \%$ did not know the symptoms of $P C$.

A very important fact in the table above is the lack of knowledge of the male population on pros-
Table 2. Percentage distribution of answers regarding knowledge of the symptoms of PC. Campina Grande/PB, September 2012.

\begin{tabular}{|c|c|c|}
\hline \multicolumn{3}{|c|}{ Knowledge of the symptoms of prostate cancer } \\
\hline Symptoms of prostate cancer & n (\%) & Total n (\%) \\
\hline Pain when urinating & $7(16.3)$ & \multirow{9}{*}{$\begin{array}{l}43^{*} \\
(100)\end{array}$} \\
\hline Difficulty urinating & $12(27.9)$ & \\
\hline Urinating aplenty & $4(9.3)$ & \\
\hline Urinating in small quantities & $2(4.6)$ & \\
\hline Urinating very often & $3(7)$ & \\
\hline Infrequently urinating & $1(2.3)$ & \\
\hline Urethral bleeding & $3(7)$ & \\
\hline $\begin{array}{l}\text { Feeling of not emptying the } \\
\text { bladder after urination }\end{array}$ & $1(2.3)$ & \\
\hline Do not know & $10(23.3)$ & \\
\hline $\begin{array}{l}\text { Source: Field Research, } \\
\text { Campina Grande/PB, 2012. *: }\end{array}$ & $\begin{array}{l}\text { cipal Hea } \\
\text { ant Minim } \\
2.00 \text { Braz }\end{array}$ & $\begin{array}{l}\text { Ith Secretary. } \\
\text { um Wage } \mathrm{R} \$ \\
\text { lian currency. }\end{array}$ \\
\hline
\end{tabular}

tate cancer symptoms, represented by $23,3 \%$ of answers.

The most common symptoms associated with prostate cancer are hematuria and polyuria, at night; weak urinary stream; pain or burning when urinating. However, with time may be difficulties in expelling urine, increasing the urgent need to urinate, blood in the urine or pain and burning during urination $[10,11,12,13]$.

In a study [12] conducted in 2010 with 100 men working in the free fair of Barreiras-BA, on the level of knowledge of men aged over 40 years old, regarding the level of information of participants about the symptoms of the man with prostate cancer, the results were that most of the respondents (56\%) did not know about the disease, $43 \%$ said they knew it, and only $1 \%$ did not answer.

Table 3 describes the knowledge of the male population about the ways of diagnosis of prostate cancer. It is observed that most of them (70\%) reported knowing the ways of how to prevent it. However, 30\% did not know them. As for the ways of how to prevent it, most of them (65\%) answered the digital rectal exam and 35\%, the blood test (PSA). 
Table 3. Percentage distribution of respondents regarding the diagnosis of prostate cancer. Campina Grande/PB, September 2012.

\begin{tabular}{|c|c|c|}
\hline Diagnosis of prostate cancer & n (\%) & Total n (\%) \\
\hline \multicolumn{3}{|c|}{ Knowledge of ways to diagnosis prostate cancer } \\
\hline Yes & $14(70)$ & \multirow{2}{*}{$\begin{array}{c}20 \\
(100)\end{array}$} \\
\hline No & $6(30)$ & \\
\hline \multicolumn{3}{|l|}{ Ways to diagnosis prostate cancer } \\
\hline Digital rectal exam & $13(65)$ & \multirow{3}{*}{$\begin{array}{c}20 \\
(100)\end{array}$} \\
\hline Blood test (PSA) & $7(35)$ & \\
\hline Diet, physical activity, health lifestyle & $0(0)$ & \\
\hline \multicolumn{3}{|c|}{ Performance of the exam (s) to diagnosis prostate cancer } \\
\hline Yes & $7(35)$ & \multirow{2}{*}{$\begin{array}{c}20 \\
(100)\end{array}$} \\
\hline No & $13(65)$ & \\
\hline \multicolumn{3}{|c|}{$\begin{array}{l}\text { Reason for non-performance of exam (s) to diagnosis } \\
\text { prostate cancer }\end{array}$} \\
\hline Fear & $2(10)$ & \multirow{3}{*}{$\begin{array}{c}20 \\
(100)\end{array}$} \\
\hline Shame/shyness & $9(45)$ & \\
\hline $\begin{array}{l}\text { Never presented prostate cancer } \\
\text { symptoms }\end{array}$ & $9(45)$ & \\
\hline \multicolumn{3}{|c|}{$\begin{array}{l}\text { Recommended age to perform the exam to diagnosis } \\
\text { prostate cancer }\end{array}$} \\
\hline 30 years old & $1(5)$ & \multirow{4}{*}{$\begin{array}{c}20 \\
(100)\end{array}$} \\
\hline 40 years old & $13(65)$ & \\
\hline 45 years old & $4(20)$ & \\
\hline 50 years old & $2(10)$ & \\
\hline \multicolumn{3}{|c|}{$\begin{array}{r}\text { Source: Field Research, Municipal Health Secretary. } \\
\text { Campina Grande/PB, 2012. *: Each informant could give } \\
\text { more than one answer. }\end{array}$} \\
\hline
\end{tabular}

Regarding the PC diagnosis by the male population, it was found that the majority $65 \%$ never took the exam; only 35\% reported having done it before. As to the reasons for non-performance, $45 \%$ reported having shame and shyness. As for the recommended age for the exam, the majority (65\%) reported being from 40 years old.

Knowledge of the ways to prevent prostate cancer is essential for men to treat future problems related to the prostate. Several tests can be used for the different ways to prevent PC: PSA laboratory tests, digital rectal examination, transrectal ultrasonography, computed tomography, ultrasound, urography, MRI, urinary tract endoscopy, biopsy, among others $[14,15,16]$.
The prostate-specific antigen (PSA) is not specific to PC. Separately, the PSA may have a predictive value around $30 \%$. The PSA is also high in cases of acute or chronic prostatitis, urinary tract infection, as well as after cycling, or have sex (for 24 hours) [17].

The DRE is relatively a preventive measure with low cost. However, it is a procedure related to the male imagination and may even keep many distant men of preventing prostate cancer. This refusal does not necessarily occur because of the lack of information about the effectiveness of this preventive measure. With common sense, well-informed men resist to this way of prevention [18].

A study [18] carried out in 2008 with 17 male employees of the University of Vale do Paraíba on knowledge and difficulties to the prevention of prostate cancer found that the main reasons leading men not to seek ways to prevention were machismo $(13 \%)$, lack of knowledge about how to prevent it (13\%), prejudice (12\%) and 9\% reported fear.

This study observed that the cultural barriers like fear, shame and shyness expressed in the answers of the respondents about the examination of prevention of prostate cancer, (especially in the digital rectal examination) are still strong in the daily life of the population, and hinder to seeks measures to prevent the disease.

The prevention and treatment of prostate cancer should consider the emotional aspects involved since many men refuse to participate in prevention or delay programs. Digital rectal examination and clinical examination seem to increase such fantasies and keep away many men the possibility of prevention and treatment of cancer [19].

A factor linked to this is the consideration that there are difficulties in this group to recognize their health needs, cultivating the thought that rejects the possibility of becoming ill, keeping today the cultural issue of male invulnerability of their social role provider and hero. A situation hindering this assistance of males is the working hours of hospital usually coincide with their working hours [20]. 
National Integral Attention to Men's Health Policy - PNAISH has emerged trying to raise awareness among the male population, calling the attention to the man in the care perspective that protect comprehensive care and that this is not restricted only to recovery, ensuring above all the prevention of avoidable diseases and health promotion. This enables nursing professionals to incorporate a qualified and directed point of view, which will make the health assistance more effective and efficient, contributing to the emergence of diseases in the male population and the reduction of complications [21].

Considering the data described in Table 3, another aspect emphasized in this study is when describing the reasons that the male population do not perform the examination for the prevention of prostate cancer, that beyond the highlighted fear, shame and shyness, this population highlights that they do not perform the examination for prevention because they do not have symptoms of the disease.

This fact is considered to be negative, because it shows that the understanding of the studied population about the concept of health is facing the traditional model of health care, which emphasizes the biological and individual aspect, to the detriment of health promotion and prevention of diseases, recommended by the health surveillance model. When the population seeks to achieve the PC prevention exam only when symptomatic, they have the risk of a larger health problem already installed, increasing the risk of worsening the problem and may lead to death.

For PC prevention, it is important that men seek health services without symptoms, to carry out the practice of rectal and performing the measurement of PSA. The control of prostate cancer should be based on educational activities aimed at male population, who should seek the outpatient clinic for an annual evaluation [2].

The following Table 4 shows the health information received by the male population about prosta-
Table 4. Percentage distribution of answers regarding the health information received about prostate cancer. Campina Grande/PB, September 2012.

\begin{tabular}{|c|c|c|}
\hline $\begin{array}{l}\text { Health information received } \\
\text { about prostate cancer }\end{array}$ & n (\%) & Total n (\%) \\
\hline \multicolumn{3}{|l|}{ Receiving information about PC } \\
\hline Yes & $14(70)$ & \multirow{2}{*}{$\begin{array}{c}20 \\
(100)\end{array}$} \\
\hline No & $6(30)$ & \\
\hline \multicolumn{3}{|c|}{ Means of information received about PC } \\
\hline Television/radio & $10(50)$ & \multirow{4}{*}{$\begin{array}{c}20 \\
(100)\end{array}$} \\
\hline $\begin{array}{l}\text { Printing journals/magazines/ } \\
\text { educational brochures }\end{array}$ & $04(40)$ & \\
\hline Educational activity (lectures) & $4(40)$ & \\
\hline $\begin{array}{l}\text { Individual guidance during a } \\
\text { professional consultation }\end{array}$ & $2(10)$ & \\
\hline \multicolumn{3}{|c|}{$\begin{array}{l}\text { Source: Field Research, Municipal Health Secretary. } \\
\text { Campina Grande/PB, 2012. *: Greater than 20, because } \\
\text { each informant could give more than one answer. }\end{array}$} \\
\hline
\end{tabular}

te cancer. It is observed that most of them (70\%) reported receiving information about the disease at any time. As for the means for which the information was received, 50\% reported the television and radio, 40\% through newspapers, magazines, educational brochures. Only 40\% reported being through educational activity in the form of lectures and $10 \%$ reported individual guidance during the consultation of a professional.

Although most respondents claiming to receive information about prostate cancer, the table above shows a small percentage reporting that information is received through educational activities (lectures) and individual guidance during the consultation of a professional.

It is known that the Family Health Team which operates in the territory of the population of this study should act as the preferred gateway for these users to actions and health services, and this team should develop educational activities and individual guidance about the importance of prevention of prostate cancer to enable this population having knowledge about the disease and its implications to avoid possible negative constructions of the di- 
sease mainly caused by cultural issues still present in society.

Among the many areas of health services, the Family Health Strategy - FHS is the gateway to the health system in a primary approach that forms the basis and determines the work of other levels of care, offering the health promotion and protection services, risk prevention, cure and rehabilitation to maximize the health and well-being, and integrating the attention of hierarchical and regionalized form besides being a privileged context for the development of educational practices in health.

It is a resource through which knowledge scientifically produced in the health field by health professionals affects the daily lives of people since the understanding of the determinants of the healthdisease process provides subsidies for the adoption of new habits and health behaviors.

Health education in Brazil has two assumptions in which the first one refers to curative and preventive measures aimed at achieving health and coping with diseases. The second assumptions are to health promotion strategies aimed at welfare and the social construction of health. The assumption of preventive and curative strategies to fight the disease and get health is consistent with the principles governing the current cultures and societies, as they are based on ceaseless production and always renewed range of services that are based on technology and science offered to consumption of individuals [22].

When talking about health education, people think about preventing diseases, looking like the health itself is revealed in an individual problem and it can be solved only by educating people. In this aspect, the health education would be seen as a way to change some individual characteristics in short, not obedience to important preventive care and necessary for health promotion [23].

Health education requires a combination of opportunities that encourage health promotion and its maintenance, not understood only as transmission of content, but also as the adoption of educational practices that seek autonomy of the subjects in the conduct of his life [24].

From the perspective of health promotion, professionals must establish some bonds and create co-responsibility links with the users who will decide what is good for them, according to their values, beliefs, expectations and needs [25].

The following categories for analysis were built to analyze critically the answers of men interviewed: I - Unawareness of the male population about prostate câncer; II - PC related to symptoms e III - PC related to prevention.

\section{Category Organizations Results in Table 5.}

Table 5. Distribution of the categories selected according to the objective of the study. Campina Grande/PB, September 2012.

\begin{tabular}{l|l|l}
\multicolumn{1}{c|}{ Objective } & \multicolumn{1}{c|}{ Main Theme } & \multicolumn{1}{c}{ Categories } \\
\hline $\begin{array}{l}\text { To investigate } \\
\text { the meaning of } \\
\text { PC for the male } \\
\text { population }\end{array}$ & $\begin{array}{l}\text { Meaning of PC } \\
\text { for the male } \\
\text { population }\end{array}$ & $\begin{array}{l}\text { I- Unawareness } \\
\text { of the male } \\
\text { population about } \\
\text { prostate cancer. } \\
\text { II - PC related to } \\
\text { symptoms } \\
\text { III - PC related to } \\
\text { prevention. }\end{array}$ \\
& & \\
& &
\end{tabular}

Source: Research data/2012

\section{Meaning of prostate cancer for the male population}

Regarding the central theme described above, it was possible to analyze and select three categories: the first category related to "the male population unawareness about the PC," the second category "PC related to symptoms," and the third category "PC related to the prevention." Below, there is the testimonies and analysis described related to each category mentioned. 


\section{Unawareness of the male population about prostate cancer}

In the identification of the users' knowledge on the meaning of prostate cancer, most respondents knew nothing about the disease, as evidenced in the following lines:

I do not understand anything about it then I do not understand...

I do not understand anything.

E.1; E.3; E.6; E.10; E.18.

I know nothing of it, you know.

I do not know, you see, I do not understand it...

I do not know, do not know...

E.12.

I cannot understand anything of a prostate cancer thing.

I do not understand anything that I do not feel anything...

A relevant fact and may be associated with lack of knowledge about prostate cancer is the education of those interviewed since most of the participants in this study were illiterate and had not completed elementary school.

A study [26] carried out in 2006 in the city of Fortaleza/CE with workers over 40 years old to assess the knowledge of the employees of a private university on the prevention of prostate cancer, found the disinformation of the male population about the problem. Most of them, 37.1\% conceptualized it as being simply a disease that affects men and a significant perceptual could not explain it.
It is believed that health education is the fundamental key to the family health team to develop activities with the population studied to enable them to know the $P C$, particularly on preventive measures, since such misinformation is a worrying factor since knowledge about the disease and ways to prevent it can be decisive on its evolution.

\section{PC related to symptoms}

Reading the speeches below allows us to infer that the meaning of prostate cancer for the male population is related to the symptoms of the disease.

It is a pain in the urethra only.

Because the person urinates one little urine three days right?... pain in the belly right? .. then, the thing is burning right?...

what I understand is that it is urinating much, difficulty urinating and pain in the bladder and various things...

it is a disease that gives a great desire to be peeing a lot; it gives much pain in the bladder and if you do not care you can die...

The speeches showed that in this population, there is no knowledge about prostate cancer. They think the disease is only installed in the body when they feel the symptoms. In this respect, it is also possible to realize in the discourse above, the idea that the health care model by which experiences this population in their daily lives is facing the biological conception of health, emphasizing the healing instead of health promotion and disease prevention.

Despite the respondents of this study rely on professionals of the Family Health Strategy in the terri- 
tory where they live, it is wondered whether these professionals are developing health promotion and disease prevention directed to the community, especially to men, or they are playing traditional models of hegemonic health care.

In this sense, the development of health promotion programs and risk prevention and disease aims to change the current health care model in the health system and to improve the quality of life, since most of the diseases affecting the population are preventable. Also, it is promoted the reduction of spending on health care high cost for companies [27].

\section{PC related to prevention}

It can be seen in the speeches below that respondents associate the meaning of prostate cancer to preventive examinations, especially the rectal exam:

...You have to do preventive tests at least; I am not sure but every year.

...If you do the correct tests monitoring there....

I know the thing is by the rectal and the person has to do over 40.

E.14.

I have to be prevented by making the rectal exam because if you notice it at the right time, you can be cured but later, it will be complicated

...the right thing is to do the rectal exam every six months, a blood test to give a general ready only this even though I know.

Although the study population did not have a broad knowledge on the disease, prevention through digital rectal examination is emphasized by this population as important, though, it still is an examination of strong cultural barriers.

It is observed in the speeches that respondents relate only the performance of the digital rectal exam to the prevention of prostate cancer. It is important to consider that beyond that examination, other tests already mentioned in this study are important for screening prostate cancer. The population needs to know the risk factors for the disease so that they can take preventive measures.

Prostate cancer and its early screening are little discussed in the male population, getting men unrelated to this serious public health problem in Brazil, which can have a negative impact on the health of people in our country, since, knowing the severity of the problem, few men seek the health services [28].

\section{Conclusions}

The results presented in this study point to the opportunity to observe and reflect on aspects that influence the knowledge of the male population in the PC:

Socioeconomic barriers, reflected in low income and low education contribute to the lack of understanding of men over the health-disease process, thus also impacting negatively on the knowledge of this population in the prostate cancer.

Cultural barriers are one of the main factors that interfere with the achievement of prostate cancer prevention exams, especially the digital rectal exam. This fact is associated with little knowledge of this population about the disease.

Although most of the population studied reported to know how to prevent prostate cancer, most of them do not do the tests for prevention, which is another negative factor, since it predisposes this population to the risks of the disease.

Although the majority of respondents said they had received information about the prostate cancer, that information is received mostly through televi- 
sion, radio, educational brochures. On the other hand, educational activities in groups by lectures and individual guidance during a professional consultation were not mentioned by respondents.

The family health team needs to work on the issues related to human health especially concerning the PC to enable the male population knowledge about the disease so that this population uses the means of prevention to care about their health. The nurse as a member of the team must have a different view, looking at the Community Health Agents and other team members enhance the health education actions to be developed with this population. This study raised interest in other studies to be carried out to enable better research on the subject.

\section{References}

1. Kuarne H. et al. Marcadores moleculares de suscetibilidade para o câncer de próstata. In: Congresso Brasileiro de Genética n ${ }^{\circ}$ 54 ${ }^{\circ}$ Bahia Othon Palace Hotel (Salvador), Bahia. Resumos do $54^{\circ}$ Congresso Brasileiro de Genética. Salvador (BA): Sociedade Brasileira de Genética; 2008. p. 206

2. Instituto Nacional de Câncer José Alencar Gomes da Silva [homepage na internet].Câncer de próstata [acesso em 26 abr 2015]. Disponível em: http://www2.inca.gov.br/wps/wcm/ connect/tiposdecancer/site/home/prostata/definicao.

3. Tofani ACA, Vaz, CE. Câncer de próstata, sentimento de impotência e fracassos antes os Cartões IV e VI do Rorschach. Revista Interamericana de Psicologia. 2007; 41(2).

4. Gianini MMS. Câncer e Gênero: Enfrentamento da doença. São Paulo. Dissertação [Mestrado em Psicologia] - Pontifícia Universidade Católica de São Paulo; 2007.

5. Sociedade Brasileira de Urologia [homepage na internet]. As doenças que ocorrem na próstata [acesso em 01 de nov de 2014]. Disponível em: http://www.sbu.org.br.

6. Brasil. Ministério da Saúde. Secretaria de Atenção à Saúde. Departamento de Ações Programáticas e Estratégicas. Política Nacional de Atenção Integral à Saúde do Homem: princípios e diretrizes / Ministério da Saúde, Secretaria de Atenção à Saúde, Departamento de Ações Programáticas e Estratégicas. Brasília: Ministério da Saúde; 2009.

7. Oliveira MM. A prevenção do câncer de colo de útero, no contexto da estratégia saúde da família, da área básica da distrital-Oeste/Sumarezinho, do município de Ribeirão Preto-SP. Ribeirão Preto. Dissertação [Mestrado] -Escola de Enfermagem de Ribeirão Preto, Universidade de São Paulo; 2003.
8. Minayo MCS. Pesquisa social: teoria, método e criatividade. Petrópolis (RJ): Vozes; 2010.

9. Bardin L. Análise do Conteúdo. Lisboa: Edições 70; 2009.

10. Costa RP. Câncer da próstata: conceitos atuais. Brasília (DF): Hosp. Amaral Carvalho; 1997.

11. Corrêa NAB. et al. Diagnóstico precoce de carcinoma de próstata: antígeno prostático específico (PSA), um marcador quase ideal. Rev. Bras. Anál. Clín. 2003; 35 (2): 63-64.

12. Reggio E. Tratamento percutâneo do adenocarcinoma de próstata por crioblação. São Paulo. Tese [Doutorado em Medicina] - Universidade de São Paulo; 2005.

13. Gonçalves IR, Padovani C, Popim RC. Caracterização epidemiológica e demográfica de homens com câncer de próstata. CienSaude Colet.2008; 13(4): 1337-1342.

14. Rodrigues CC, Pereira GG, Frota WSN, Lopes YC, Almeida, LS. Câncer de Próstata: nível de conhecimento da população masculina com faixa etária acima de 40 anos, da feira livre do município de Barreiras-BA [Apresentação na III Jornada Científica e Tecnológica do Oeste Baiano; 2010; Bahia, Brasil].

15. Otto SE. Oncologia: câncer em enfermagem. São Paulo (SP): Reichmann e Affonso; 2002.

16. Nettina SM. Prática de enfermagem. 7. ed. Rio de Janeiro (RJ): Guanabara Koogan; 2003

17. Miranda PSC, Côrtes MCJW, Martins ME, Chaves PC, Santarosa RC. Práticas de diagnóstico precoce de câncer de próstata entre professores da faculdade de medicina - UFMG. Rev. Assoc. Med. Bras. 2004; 50(3): 272-275.

18. Kelleher D. Problemas de próstata e ITUs. Medical Update. 2003; 1(5):11-2.

19. Gomes R. et al. A prevenção do câncer de próstata: uma revisão da literatura. CienSaude Colet. 2008; 13 (1): 239-242.

20. Maia KO, Moreira SH, Filipini S M. Conhecimento e dificuldade em relação à prevenção do câncer de próstata na ótica dos homens de meia idade. In: Anais do $13^{\circ}$ Encontro Latino Americano de Iniciação Científica, $9^{\circ}$ Encontro Latino Americano de PósGraduação: ciência e ética, o paradigma do século XXI; 2009 out 16-17; São José dos Campos, Brasil. São Paulo: UNIVAP; 2009.

21. Vieira ACOA, PompeoACL, Lucon AM. Repercussões da comunicação do diagnóstico de câncer da próstata na sexualidade masculina. Revista Brasileira de Medicina. 2005:1014.

22. Schraiber LB, Figueiredo WS. et al. Necessidades de saúde e masculinidades: atenção primária no cuidado aos homens. CadSaude Publica. 2010; 26 (5): 961-70.

23. Silva SO. Cuidado na perspectiva de homens: um olhar da enfermagem [dissertação]. Santa Maria: Universidade Federal de Santa Maria; 2010. 
24. Guedes MVC, Silva LF, Freitas MC. Educação em saúde: objeto de estudo em dissertações e teses de enfermeiras no Brasil. Rev. Bras Enferm. 2004; 57 (6): 662-5.

25. Lima MADS. Educação em Saúde: algumas reflexões e implicações para a prática de enfermagem. Rev Gaucha Enferm. 1996; 17(2): 87-91.

26. Pereira JRS. et al. Conhecimento de mototaxistas do município de Sobral sobre detecção do câncer de próstata. RevScientia Mater. 2003; 2(1): 79-93.

27. Pedrosa II. É preciso repensar a educação em saúde sob a perspectiva da participação social. Disponível em: < $\underline{w w w}$. gicessc.org>. Acesso em: 20 jun. 2015. Entrevista cedida a Radis, 2003.

28. Lima ACF. Conhecimento dos trabalhadores de uma universidade sobre o Câncer de Próstata. CogitareEnferm. 2007; 12(4): 460465.

29. Brasil. Ministério da Saúde. Promoção da saúde e prevenção de riscos e doenças na saúde suplementar: manual técnico/ Agência Nacional de Saúde Suplementar. 2. ed. rev. e atual. Rio de Janeiro: ANS; 2007.

Publish in International Archives of Medicine

International Archives of Medicine is an open access journal publishing articles encompassing all aspects of medical science and clinical practice. IAM is considered a megajournal with independent sections on all areas of medicine. IAM is a really international journal with authors and board members from all around the world. The journal is widely indexed and classified Q2 in category Medicine. 